\title{
A Preliminary Study on Vegetation Structure and Mangrove Diversity in Irakkandy Lagoon, Trincomalee
}

\author{
K. Krishnanantham ${ }^{1}$, Y.B.M.C.J. Seneviratne ${ }^{2}$ and S.C. Jayamanne ${ }^{1^{*}}$ \\ ${ }^{1}$ Uva Wellassa University, Badulla, Sri Lanka \\ ${ }^{2}$ GEF/IFAD-PCZRSM Project office, Department of Coast Conservation and Coastal Resource \\ Management, Trincomalee, Sri Lanka
}

Date Received: 22-11-2014 Date Accepted: 29-04-2015

\begin{abstract}
The present study was carried out during the period from May to July 2014 to assess the vegetation pattern and to estimate biomass of the mangroves in Irakkandy Lagoon, Trincomalee. Five belt-transects of $10 \mathrm{~m}$ in width were laid perpendicular to the shoreline. Data were collected on tree diameter at breast height $(\mathrm{dbh})$ and tree height from each sub-plot $\left(100 \mathrm{~m}^{2}\right)$ in belt transects using standard methods. Above ground biomass, basal area and relative density of the mangroves were also estimated. Diversity and evenness of each sub-plot was calculated using Shannon-Wiener diversity index and Pielou's evenness index respectively. Results revealed that the study site is composed of 5 true mangrove species and highest density was recorded for Avicennia marina (414 trees/ha, 700 saplings/ha, 2354 seedlings/ha), followed by Lumnitzera racemosa, Excoecaria agallocha, Rhizophora apiculata and Heritiera littoralis. The greatest mangrove diversity (1.28) was observed in subplot 1 of transect 2. The least mangrove diversity (0) was found in transect 5. There is a significant difference among transects concerning the diversity and evenness $(\mathrm{P}<0.05)$. The results showed that Avicennia marina was the dominant species with Height $(\mathrm{H})$ and dbh of $3.65 \pm 1.43 \mathrm{~m}$ and $5.06 \pm 1.07 \mathrm{~cm}$ respectively, followed by Lumnitzera racemosa $(3.36 \pm 1.19 \mathrm{~m}$ and $5.81 \pm 1.06 \mathrm{~cm}$, Excoecaria agallocha $(4.92 \pm 2.45 \mathrm{~m}$ and $5.31 \pm 1.93 \mathrm{~cm})$, Rhizophora apiculata $(4.56 \pm 1.70 \mathrm{~m}$ and $4.89 \pm 0.96 \mathrm{~cm})$ and Heritiera littoralis $(8.80 \pm 0.849 \mathrm{~m}$ and $26.50 \pm 4.95 \mathrm{~cm})$. The above ground biomass of Lumnitzera racemosa was recorded as $8334.89 \mathrm{~kg} / \mathrm{ha}$ and Avicennia marina was recorded as $1361.13 \mathrm{~kg} / \mathrm{ha}$. Species diversity (H') of whole mangrove area studied was 0.86 and evenness (E) was 0.54. It reveals that Irakkandy Lagoon consists of fairly high biological diversity (Diversity index $=0.86$ ) of mangroves and extremely valuable for stability of the ecosystem.
\end{abstract}

Keywords: mangroves, biomass, diversity, Irakkandy

\section{Introduction}

Mangroves are woody plants, which grow in loose wet soils of brackish-to-saline estuaries and shorelines in the tropics and sub-tropics (Joshi and Ghose, 2003). Approximately 25\% of the world's tropical coastline is comprised of mangrove ecosystems. They are estimated to be an area between $167,000 \mathrm{~km}^{2}$ and $181,000 \mathrm{~km}^{2}$, in 112 countries (Spalding et al., 1997; Kathiresan and Bingham, 2001).

\footnotetext{
*Correspondence: sepalikauwu@yahoo.com Tel: +94718538975

ISSN 2235-9370 Print/ISSN 2235-9362 Online ㄷ University of Sri Jayewardenepura
} 
Sri Lanka is one of the South Asian countries situated in the central of the Indian Ocean, contains mangrove forests mainly along the northern, north-eastern and eastern coastal lagoons and river estuaries. Nearly 23 true mangrove species of trees and shrubs have been recorded in Sri Lanka (De Silva and De Silva, 1998). Mangroves play a vital role in the ecosystem, by supporting the sustenance of coastal biodiversity (Ronnback, 1999), Ecotourism (Ong and Gong, 2013), production of food by photosynthesis (Miththapala, 2008), and medicinal value by highest antibacterial activity (Abeysinghe, 2010).

Information available in literature for mangrove ecosystem is scanty for the eastern region of Sri Lanka. The pressure on mangrove ecosystem increased at an alarming rate during the past two decades due to ethnic conflict and at present due to development activities. In addition, Tsunami 2004 has collectively contributed to the destruction of mangroves at large in the Eastern province. Moreover, people living in association with the mangrove and rely on the mangroves for their sustenance and livelihood would also be affected.

Irakkandy Lagoon is situated in Trincomalee District and associated with rich mangrove resources. However, the mangroves of Irakkandy have not been studied up to date and there are no published information regarding the mangroves in Irakkandy Lagoon. Information such as vegetation structure, species diversity, density of the stands of mangroves are very important for planning management strategies and conservation of mangroves and the present study was aimed at providing such information required for management of the mangroves in the Irakkandy Lagoon.

\section{Methodology}

\subsection{Site selection}

Irakkandy lagoon is located in Eastern Province of Sri Lanka; the estimate terrain elevation above sea level is $12 \mathrm{~m}$. It has high mangrove distribution and one of the famous ecosystems in Trincomalee district belongs to Kuchchaveli DS Division.

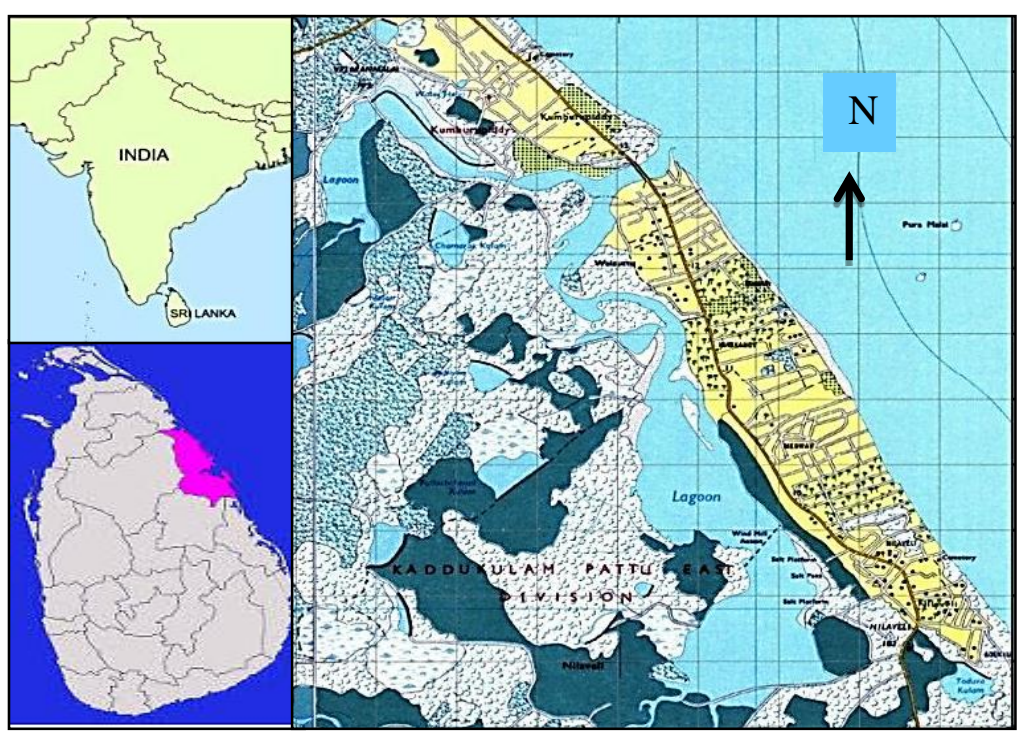

Figure 1: Map of the Irakkandy Lagoon.

(Source: Google earth- http://www.geody.com) 
One of the branches of this lagoon begins from $8^{\text {th }}$ mile post while other branch starts from Kumburupity South Sinna Karachi and both joins the sea near Irakkandy River mouth. The lagoon includes four GN Divisions named Vaalaiuttru, Irakakandy, Kumburupity East and Kumburupity South.

\subsection{Vegetation structure}

Data were collected from May to July 2014 at the selected samples. Five sampling sites were chosen randomly to carry out the study (Figure 2). Georeferencing was done by the portable GPS unit (Garmin ${ }^{\circledR}$ Etrex 10). Five belt-transects of $10 \mathrm{~m}$ in width were laid perpendicular to the shoreline in each sites. Each transect was sub-divided into $10 \times 10 \mathrm{~m}$ with three sub-plots $\left(100 \mathrm{~m}^{2}\right)$ and data on mangrove vegetation structure, i.e., species, tree diameter at breast height (dbh), tree height $(\mathrm{H})$, density and basal area were obtained from each sub-plot $\left(100 \mathrm{~m}^{2}\right)$. Above ground biomass and relative density of the mangroves were also estimated.

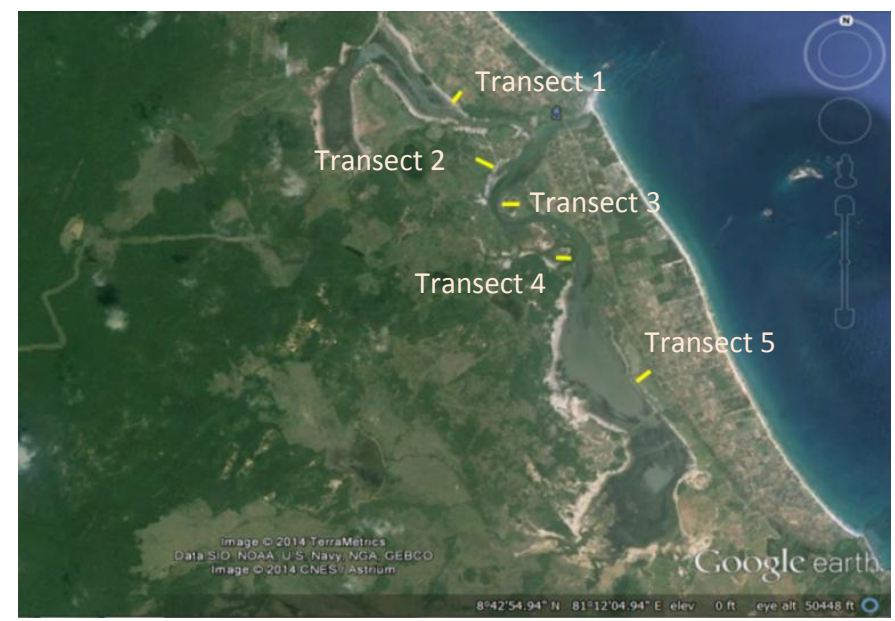

Figure 2: Location of transects in Irakkandy Lagoon.

(Source: Google earth)

\subsection{Diversity estimation}

The mangrove species were identified and recorded by using identification keys (Ministry of Environment and Natural Resources, 2007). Mangrove diversity of each transect was calculated using Shannon Weiner Index (equation 1) (Shannon and Weaver, 1949).

$$
\begin{aligned}
& H^{\prime}=-\sum_{i=1}^{s} P_{i} \log P_{i} \\
& \text { where: } \quad \begin{aligned}
H^{\prime}= & \text { Shannon diversity index } \\
P_{i}= & \text { fraction of the entire population made up of species i (proportion of a } \\
& \text { species i relative to total number of species present, not encountered) } \\
S= & \text { numbers of species encountered }
\end{aligned}
\end{aligned}
$$

High value of $\mathrm{H}^{\prime}$ would be a representative of a diverse and equally distributed community and lower values represent less diverse community. A value of 0 would represent a community with just one species. The evenness of the species was calculated by the Pielou's Evenness Index (Pielou, 1966) using in equation 2. 


$$
\begin{aligned}
& e=H^{\prime} / l n S \\
& \text { where: } \begin{aligned}
H^{\prime} & =\text { Shannon diversity index } \\
S & =\text { Total number of species in the sample } \\
& =\text { Pielou's Evenness Index }
\end{aligned}
\end{aligned}
$$

The above-ground biomass (AGB) of the mangrove stands was estimated using the allometric relationship between above-ground biomass, diameter at breast height $(d b h)$ and height (Cintron and Schaeffer-Novelli, 1984; Komiyama et al., 1988; Tam et al., 1995; Komiyama et al., 2000). Equations 3 to 8 illustrate the methods used to estimate them.

Avicennia marina

$$
A G B=123.59\left[(D B H)^{2} H\right]^{0.529}
$$

\section{Rhizophora apiculata}

$$
A G B=23.64\left[(D B H)^{2} H\right]^{0.529}
$$

Lumnitzera racemosa

$$
A G B=102.30(D B H \quad)^{2.5}
$$

$$
\mathrm{p}
$$

Stand Basal Area and Relative density were calculated following equations (English et al., 1994).

Basal area

$$
B A=\frac{\pi D B H^{2}\left(\mathrm{~cm}^{2}\right)}{4}
$$

Stand Basal area

$$
\text { Stand } B A=\frac{\sum B A}{\text { Area of the plot }} \mathrm{m}^{2} \mathrm{ha}^{-2}
$$

Relative density

$$
R D=(\text { No. of individuals of a species/Total no. of individuals in all species }) \times 100
$$

\subsection{Statistical analysis}

General Linear Model (ANOVA) and correlation were employed to analyse the data using MINITAB 16 software.

\section{Results}

3.1 Identification of true mangrove plants and mangrove associated plants

Table 1 indicates identified true mangrove species during study period in Irakkandy Lagoon. 
Table 1: Identified mangrove plants in Irakkandy Lagoon.

\begin{tabular}{lll}
\hline \multicolumn{1}{c}{ Family } & \multicolumn{1}{c}{ Species name } & \multicolumn{1}{c}{ Local Name } \\
\hline Avicenniaceae & Avicennia marina (Forssk.)Vierh & Manda (SN), Venkandal (TN) \\
Combretaceae & Lumnitzera racemosa Willd & Beriya (SN), Tipparuthin (TN) \\
Euphorbiaceae & Excoecaria agallocha L. & Telakiriya (SN), Tilai (TN) \\
Rhizophoraceae & Rhizophora apiculata Blume. & Kadol (SN), Kandal (TN) \\
Sterculiaceae & Heritiera littoralis Dryand. & Etuna (SN), Choomuntiri (TN) \\
\hline
\end{tabular}

Five true mangrove species belonging to five different families were identified from the Irakkandy Lagoon. Avicennia marina (Avicenniaceae) was the dominant species while Heritiera littoralis (Sterculiaceae) was rare. Figure 3 shows the morphological characteristics of the species in the table 1.
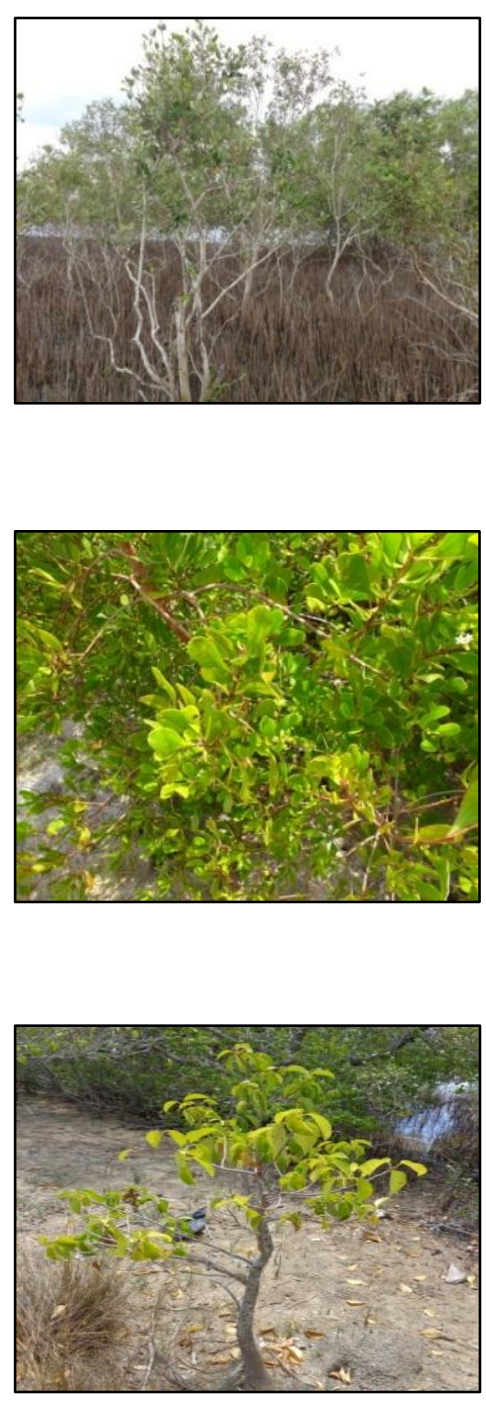

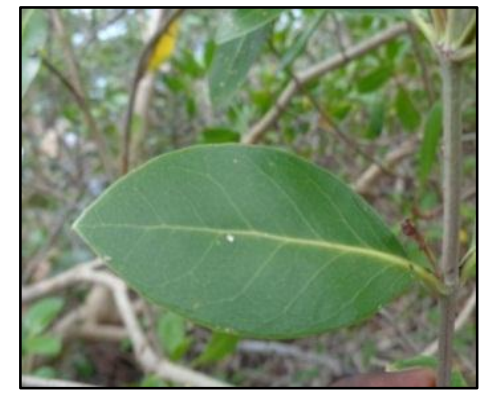

3a: Avicennia marina

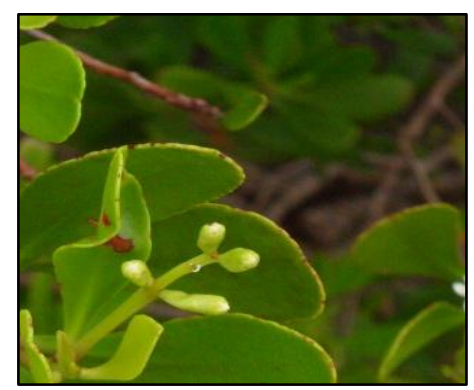

3b: Lumnitzera racemosa
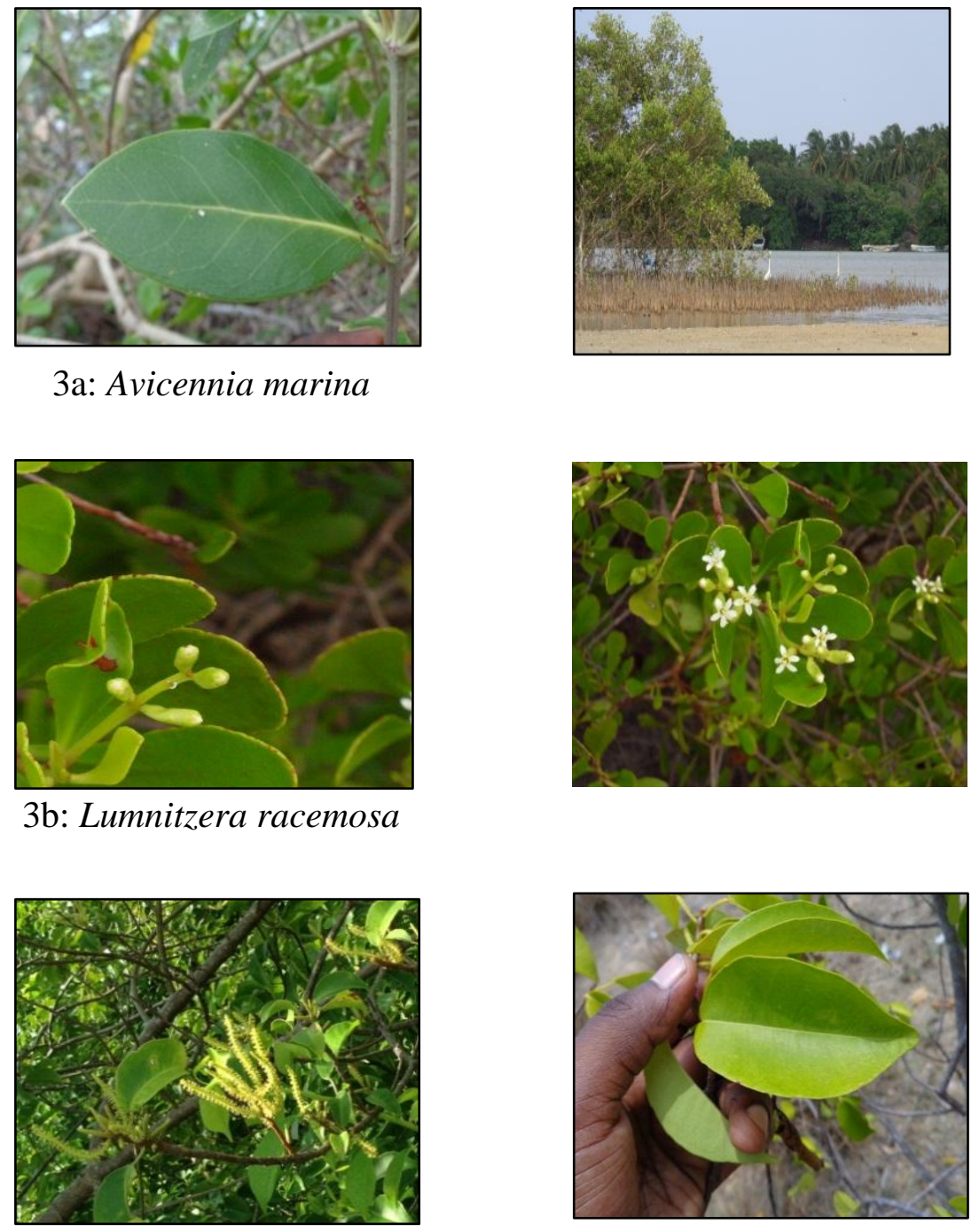

3c: Excoecaria agallocha 

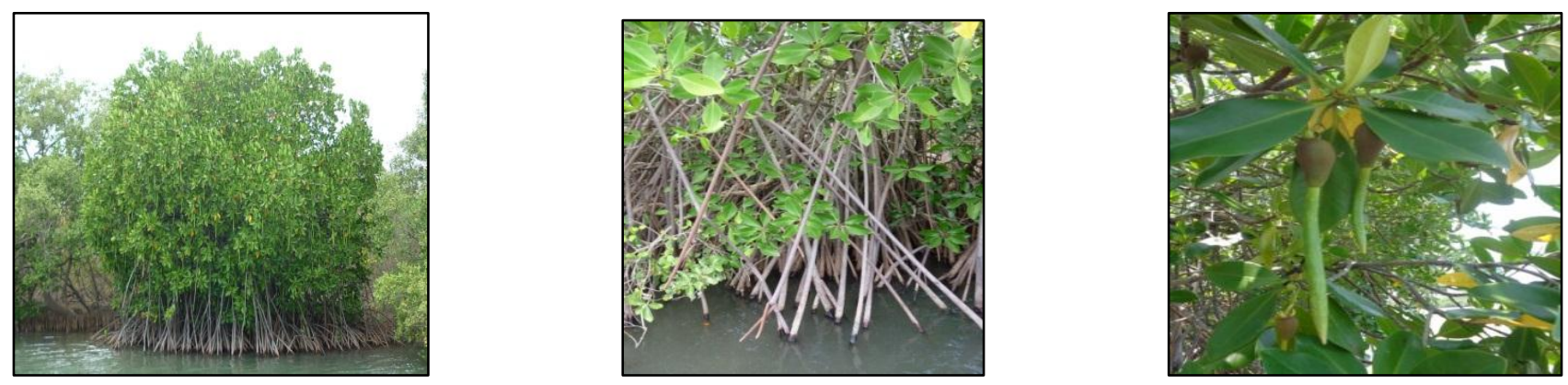

3d: Rhizophora apiculata
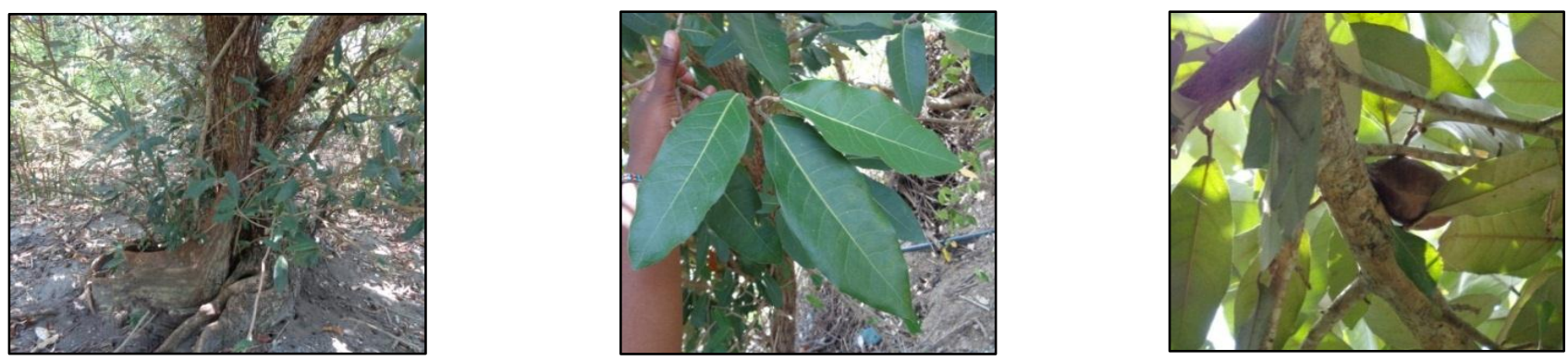

3e: Heritiera littoralis

Figure 3: Morphological characteristics of true mangroves found in Irakkandy Lagoon.

\subsection{Mangrove associated plants}

Nine mangrove associated plants (Table 2) were identified in Irakkandy Lagoon during the study period. Figure 4 illustrates their morphological characteristics.

Table 2: Identified Mangrove associated Plants in Irakkandy Lagoon.

\begin{tabular}{lll}
\hline Family & Mangrove associate plants & Local Name \\
\hline Verbenaceae & Premna integrifolia L. & Mahamidi (SN), Munnai (TN) \\
Verbenaceae & Clerodendrum inerme Garetn. & Walgurentha (SN), Pichuvilaaththi (TN) \\
Arecaceae & Phoenix pusilla L. & Wal inthi (SN), Eechchai (TN) \\
Fabaceae & Caesalpinia bonduc L. & Kumburuwel (SN), Kalachchi (TN) \\
Sapotaceae & Mimusops elengi L. & Munamal (SN), Mahil (TN) \\
Salvadoraceae & Salvadora persica L. & Perungoli, Karkol (TN) \\
Malvaceae & Thespesia populnea L. & Gansooriya (SN), Poovarasu (TN) \\
Pandanacea & Pandanus tectorius Parkinson ex Zucc. & Vaetakeiyya (SN), Thaalai (TN) \\
Vitaceae & Cissus quadrangularis L. & Pirandai (TN) \\
\hline
\end{tabular}




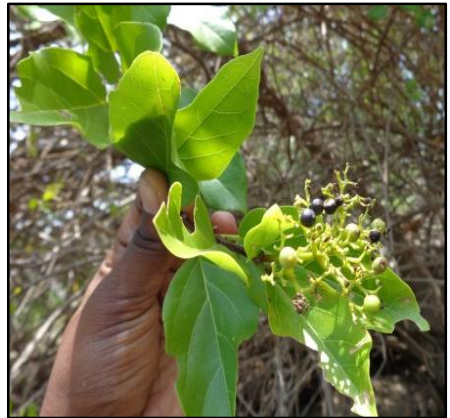

4a: Premna integrifolia

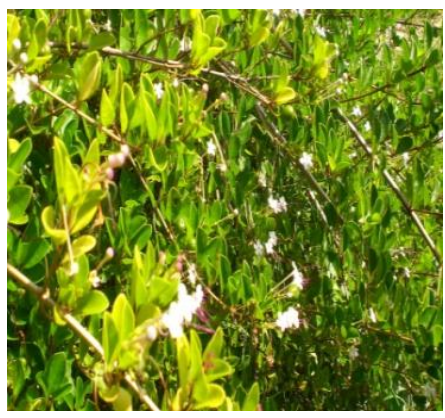

4d: Clerodendrum inerme

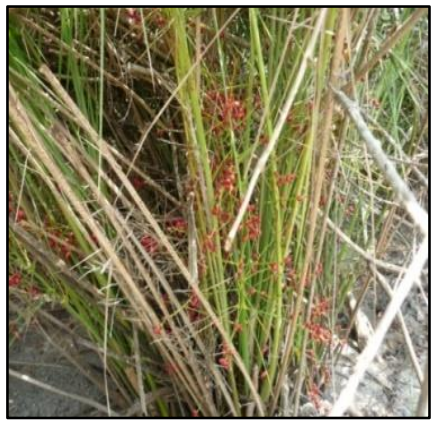

4g: Phoenix pusilla

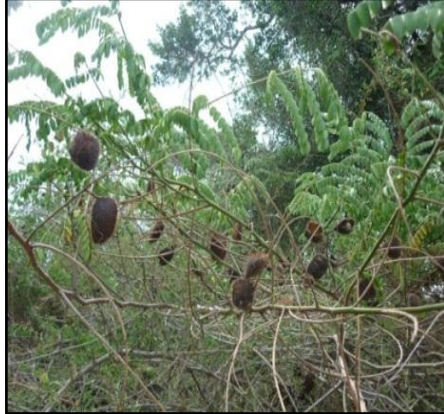

4b: Caesalpinia bonduc

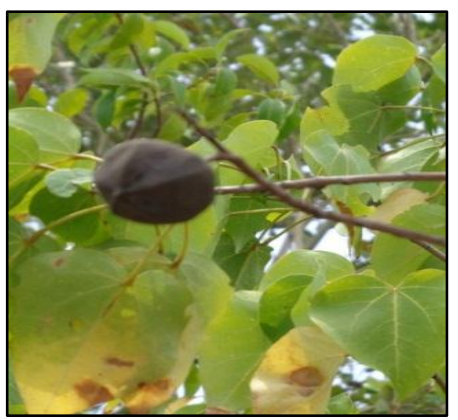

4e: Thespesia populnea

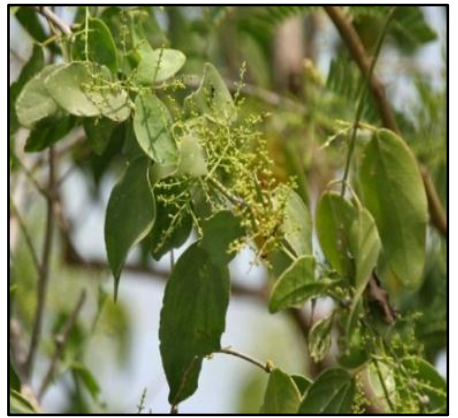

4h: Salvadora persica

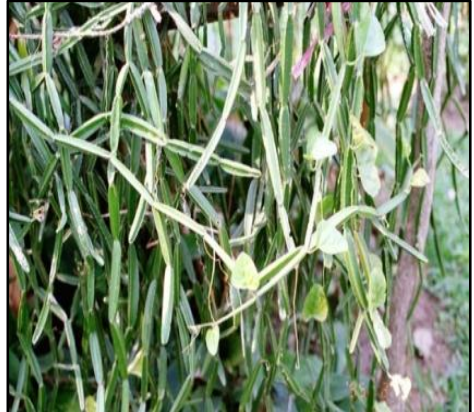

4c: Cissus quadrangularis

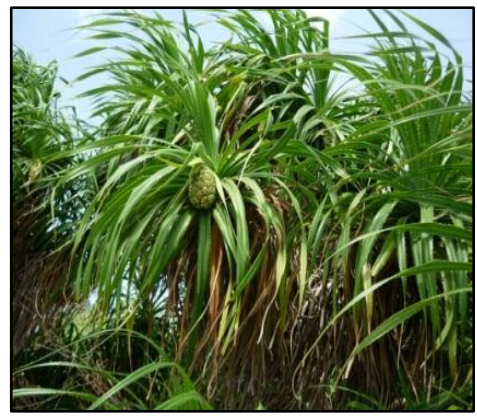

4f: Pandanus tectorius

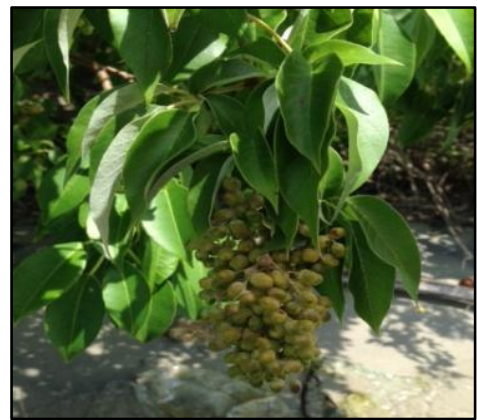

4i: Mimusops elengi

Figure 4: Morphological characteristics of the mangrove associates found in the Irakkandy Lagoon. 


\subsection{Species richness}

Species richness of the fifteen sub-plots is given in Figure 3. As indicated by Figure 3, species richness was high in Sub-plot 3 and Sub-plot 4.

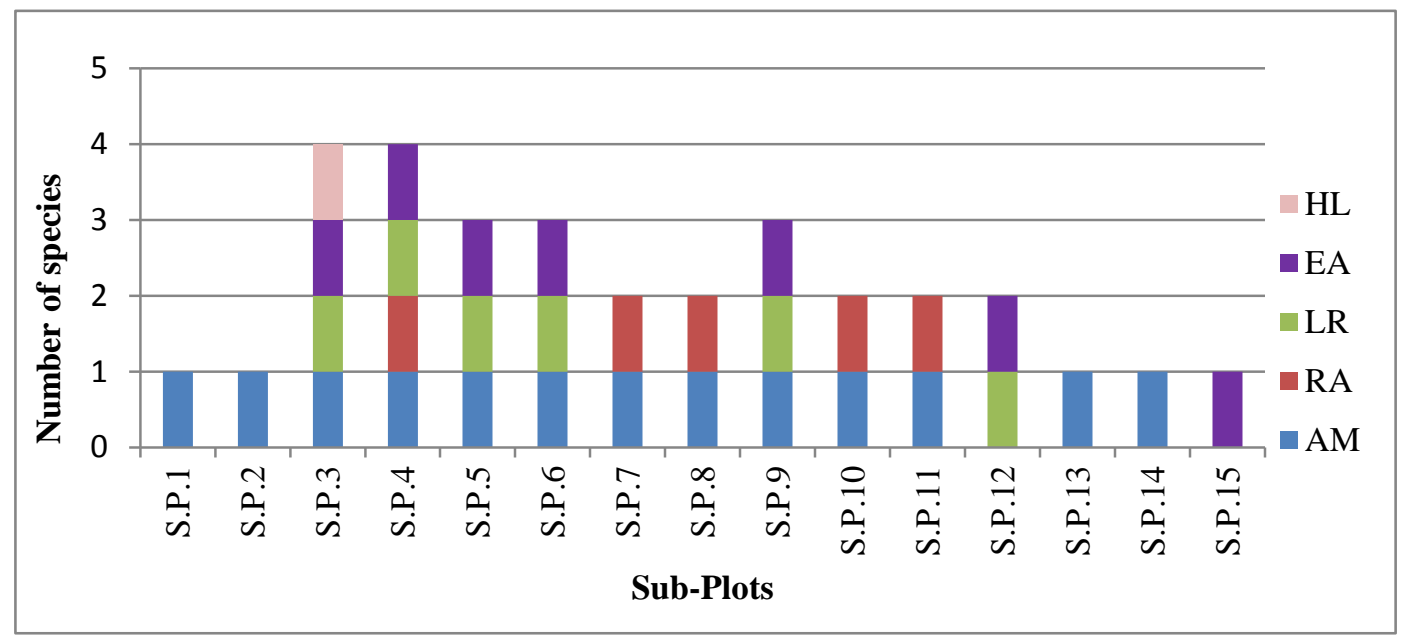

Figure 3: Species richness in each plots.

(Transect 1: SP1- SP3, Transect 2: SP4- SP6, Transect 3: SP7- SP9, Transect 4: SP10- SP12, Transect

5: SP13- SP15, Am=Avicennia marina, $\mathrm{Ra}=$ Rhizophora apiculata, $\mathrm{Lr}=$ Lumnitzera racemosa, $\mathrm{Ea}=$ Excoecaria agallocha, $\mathrm{Hl}=$ Heritiera littoralis $)$.

\subsection{Floristic Composition of mangroves in Irakkandy Lagoon}

Floristic composition of mangroves in five transects in Irakkandy Lagoon are depicted in Table 3. Percentage of individual species encountered in each belt transect are given.

Table 3: Floristic composition of mangroves in five belt transects in Irakkandy Lagoon.

\begin{tabular}{lrrrrr}
\hline & \multicolumn{6}{c}{ Percentage of mangrove species in each transects (T) } \\
\hline True mangrove species & $\mathbf{1}$ & $\mathbf{2}$ & $\mathbf{3}$ & $\mathbf{4}$ & $\mathbf{5}$ \\
Avicennia marina & 22.12 & 4.62 & 49.04 & 17.49 & 6.73 \\
Rhizophora apiculata & 0.00 & 23.92 & 38.04 & 38.04 & 0.00 \\
Lumnitzera racemosa & 20.00 & 30.00 & 35.00 & 15.00 & 0.00 \\
Excoecaria agallocha & 13.46 & 30.77 & 15.39 & 23.08 & 17.30 \\
Heritiera littoralis & 100.00 & 0.00 & 0.00 & 0.00 & 0.00 \\
\hline
\end{tabular}

Avicennia marina (Avicenniaceae) dominated all belt transects. Rhizophora apiculata (Rhizophoraceae) was not observed in T1 and T5 while Lumnitzera racemosa (Combretaceae) was not observed in T5 compared to other transects. Excoecaria agallocha (Euphorbiaceae) was found in all transects, while Heritiera littoralis (Euphorbiaceae) was observed only in T1.

Table 4 depicts the Shannnon diversity index and Pielou's index observed in each transects. High value of Shannon-Wiener index (1.352) was observed in Transect 2 while the least mangrove diversity was found in Transect 5. T2 has high species evenness (0.975) while T1 has low species evenness (0.367). The maximum evenness index value observed was $(0.975)$ while highest ShannonWiener index value was 1.352 . Hence the highest diversity was observed in Transect 2. 
Table 4: Shannnon diversity index and Pielou's index by transects.

\begin{tabular}{lccccc}
\hline & \multicolumn{5}{c}{ Transects (T) } \\
\cline { 2 - 6 } True Mangrove Species & 1 & 2 & 3 & 4 & 5 \\
Shannon-Wiener index & 0.509 & 1.352 & 0.644 & 0.973 & 0.507 \\
Pielou's evenness index & 0.367 & 0.975 & 0.464 & 0.702 & 0.731 \\
\hline
\end{tabular}

\subsection{Existence number of mangrove trees, sapling and seedlings}

Table 5: The existent number of mangrove trees, saplings and seedlings.

(Tree $=\mathrm{D}>4 \mathrm{~cm}$; Sapling $=\mathrm{D}<4 \mathrm{~cm}, \mathrm{H}>1 \mathrm{~m}$; Seedling $=\mathrm{H}<1 \mathrm{~m}$ )

\begin{tabular}{lccc}
\hline Mangrove species & Trees/ha & Saplings/ha & Seedlings/ha \\
\hline Avicennia marina & 414 & 700 & 2354 \\
Lumnitzera racemosa & 160 & 94 & 14 \\
Excoecaria agallocha & 140 & 174 & 34 \\
Rhizophora apiculata & 100 & 334 & 180 \\
Heritiera littoralis & 14 & 0 & 0 \\
\hline
\end{tabular}

Avicennia marina was the most abundant tree with 414 trees/ha followed by Lumnitzera racemosa (160 teees/ha), Excoecaria agallocha (140 trees/ha), Rhizophora apiculata (100 trees/ha) and Heritiera littoralis (14 trees/ha). Moreover, Avicennia marina sapling showed the highest dispersal followed by Rhizophora apiculata, Excoecaria agallocha and Lumnitzera racemosa. When considering the seedlings, Avicennia marina was the highest dispersal (2354 seedlings/ha) followed by Rhizophora apiculata, Excoecaria agallocha and Lumnitzera racemosa. Table 6 depicts the mean height, dbh, relative density and basal area of mangrove stand.

Table 6: Height, dbh, relative density and basal area of species.

\begin{tabular}{lcccc}
\hline Mangrove Species & $\begin{array}{c}\text { Mean Height } \\
(\mathrm{m})\end{array}$ & $\begin{array}{c}\text { Mean dbh } \\
(\mathrm{cm})\end{array}$ & $\begin{array}{c}\text { Relative density } \\
(\%)\end{array}$ & $\begin{array}{c}\text { Basal Area } \\
\left(\mathrm{m}^{2} / \mathrm{ha}\right)\end{array}$ \\
\hline Avicennia marina & $3.65 \pm 1.42$ & $5.06 \pm 1.07$ & 73.65 & 0.87 \\
Lumnitzera racemosa & $3.36 \pm 1.19$ & $5.82 \pm 1.06$ & 5.67 & 0.44 \\
Excoecaria agallocha & $4.93 \pm 2.44$ & $5.31 \pm 1.93$ & 7.37 & 0.35 \\
Rhizophora apiculata & $4.56 \pm 1.70$ & $4.89 \pm 0.97$ & 13.03 & 0.20 \\
Heritiera littoralis & $8.80 \pm 0.85$ & $26.50 \pm 4.95$ & 0.28 & 0.75 \\
\hline
\end{tabular}

The highest tree height $(8.8 \mathrm{~m})$ and $\mathrm{dbh}(26.5 \mathrm{~cm})$ were observed belongs to Heritiera littoralis which could be found far from the shore. The lowest total basal area was recorded by Rhizophora apiculata as $0.20 \mathrm{~m}^{2} / \mathrm{ha}$. Some of the mangrove species like H. littoralis, E. agallocha, and $L$. racemosa were observed far from the shore. A. marina and $R$. apiculata presence could be found in the edge of the shore line often. Table 7 shows the above-ground biomass for the mangrove species.

Table 7: Above-ground biomass of mangrove species.

\begin{tabular}{ll}
\hline Mangrove species & Above ground biomass (kg/ha) \\
\hline Avicennia marina (Avicenniaceae) & 1361.1 \\
Lumnitzera racemosa (Combretaceae) & 8334.9 \\
Rhizophora apiculata (Rhizophoraceae) & 377.2 \\
\hline
\end{tabular}


Above-ground biomass of $A$. marina has been found out as $1362.1 \mathrm{~kg} / \mathrm{ha}$ while above-ground biomass of $R$. apiculata was found out as $377.2 \mathrm{~kg} / \mathrm{ha}$. There is a significant difference among transects concerning the diversity and evenness $(\mathrm{P}<0.05)$. There is a positive moderate linear relationship between mangrove species and distance from the shore $(\mathrm{P}<0.05)$ and no significant difference found between mangrove species and tree height $(\mathrm{P}>0.05)$.

\section{Discussion}

Diversity is the total range of plant species features in an area (Kamaruzaman et al., 2007). The calculation of Shannon-Wiener index simply expresses the number of different species in a particular area. A high value of Shannon-Wiener index (1.352) would be a representative of a diverse and equally distributed community in Transect 2 and lowest value (0.507) represent less diverse community in transect 5. Species evenness is a measure of biodiversity which quantifies how equal the populations are numerically (Kamaruzaman et al., 2007). Pielou's evenness index which is the relative abundance with each mangrove species is represented in an area. Transect 2 where all the mangrove species are represented by the same number of individuals has high species evenness (0.975). Transect 1 where some species are represented by many individuals and other species are represented by very few individuals has low species evenness (0.367).

Pinto (1982) has indicated that presence of a Rhizophora border on the shore may be due to its morphological adaptations in resisting water currents with the help of prop roots. Presence of a Rhizophora border occurs may be due to the depth and slope as well as due to the lack of sandy soil and poor aeration. Some of the mangrove species like H. littoralis, E. agallocha, L. racemosa were observed far from the shore. De Silva and De Silva, (1998) has explained that in Sri Lanka, H. littoralis grows away from the tidal influence.

There is a positive moderate linear relationship between mangrove species and distance from the shore $(\mathrm{P}<0.05)$. Saha and Choudhury (1995) have reported that mangrove forest experiencing total diurnal inundation is dominated by A. marina while E. agallocha dominate sites that are not completely inundated. It can be clearly shown in Irakkandy Lagoon. Amarasinghe et al. (2013) has found that $A$. marina do not grow in fresh water and may be obligate halophytes. Also they explained that $E$. agallocha survives well in fresh water and may not have obligatory requirement for salt beyond trace amount.

Mangrove vegetation structural data at Kadolkele in Negombo estuary shows that higher numbers of species, densities, and heights occur at the areas close to the shoreline that get inundated with estuarine waters most frequently than in the landward areas that are dominated by A. marina (Jayakody et al., 2008). The abundance of saplings and seedlings gives an indication of the natural regeneration occurring (Kamaruzaman et al., 2007). The highest total of saplings and seedlings were recorded for $A$. marinawas $700 \mathrm{ha}^{-1}$ and 2,354 $\mathrm{ha}^{-1}$ respectively. From this data, total number of seedling per hectare showed a good regeneration potential. H. littoralis only occur in one plot shows low of distribution (Kamaruzaman et al., 2007).

\section{Conclusion}

A total of five mangrove species from different families were identified in Irakkandy Lagoon. Avicennia marinawas dominated this study area with 414 trees/ha recorded while, Heritiera littoralis showed very low number with only 14 trees/ha recorded. This forest type has a potential regeneration since high total numbers of seedling per hectare $(2,582)$ were observed. Total tree basal area for this 
study area is $2.597 \mathrm{~m}^{2} / \mathrm{ha}$. The greatest mangrove diversity (1.352) in terms of species richness is highest in transect 2 and the lowest mangrove diversity (0.507) was belongs to transect 5. Species diversity $\left(\mathrm{H}^{\prime}\right)$ of whole mangrove area studied was 0.86 and evenness $(\mathrm{E})$ was 0.54 . The results of the study indicate Irakkandy Lagoon consists of low biological diversity of mangroves compared to Negombo, Chilaw and Puttalam Lagoons but is extremely valuable as a living mangrove forest due to its extent.

\section{Acknowledgement}

The authors acknowledge The Department of Coast Conservation and Coastal Resources Management for the field activities.

\section{References}

Abeysinghe, P.D. 2010. Antibacterial activity of some medicinal mangroves against antibiotic resistant pathogenic bacteria. Indian Journal of Pharmaceutical Sciences. 72(2): 167-172.

Amarasinghe, M.D., De Silva, K., Jayakody, J. and Pahalawattaarachchi, V. 2008. Vegetation structure and potential gross primary productivity of mangroves at Kadolkele in Meegamuwa (Negombo) estuary, Sri Lanka. Sri Lanka Journal of Aquatic Sciences. 13: 95-108.

Amarasinghe, M.D. 2013. Vegetation Structure and Species Distribution of Mangroves along a Soil Salinity Gradient in a Micro Tidal Estuary on the North-western Coast of Sri Lanka. M. Phil. Thesis. University of Kelaniya, Sri Lanka.

Baker,V., English,S. and Wilkinson,C. 1994. Survey Manual for Tropical Marine Resources. Australian Institute of Marine Science, Townsville, pp 368.

Bingham B.L. and Kathiresan, K. 2001. Biology of mangroves and mangrove ecosystems. Journal of Advances in Marine Biology. 40: 81-251.

Biodiversity Secretariat, Ministry of Environment and Natural Resources, 2007. A field guide to the mangroves of Sri Lanka. Protected Area Management and Wildlife Conservation Project.

Blasco. F., Field C.D. and Spalding, M.D. 1997. World Mangrove Atlas. Okinawa (Japan): International Society for Mangrove Ecosystems.

Bowen, J., Valiela, I. and York, J. 2001. Mangrove Forests: One of the World's Threatened Major Tropical Environments. Bioscience. 51(10): 807-815.

Chen, G.Z., Lan, C.Y.,Tam, N.F.Y. and Wong, Y.S. 1995, Community structure and standing biomass of a mangrove forest in Futian Nature Reserve, Shenzhen, China. Hydrobiologia. 295: 193-201.

Choudhury. A. and Saha, S. 1995. Vegetation analysis of restored and natural mangrove forests in Sagar Island, Sundarbans, East coast of India. Indian Journal of Marine Sciences. 24: 133-136.

Cintron, G., Schaeffer-Novelli, Y. 1984. Methods for studying mangrove structure, in: Snedaker, J.G., Snedaker, S.C. (Eds.), The Mangrove Ecosystem: Research Methods. UNESCO, Bungay, United Kingdom, pp. 91-113.

De Silva, M. and De Silva, P.K.1998. Status, diversity and conservation of the mangrove forests of Sri Lanka. Journal of South Asian Natural History. 3(1): 79-102.

District Project Office, Department of Coast Conservation and Coastal Resource Management. Trincomalee. 2013 Sri Lanka. Primary Data Collection: Trincomalee District.

Fujimoto, K., Havanond, S., Ishihara, S., Komiyama, A., Miyagi, T., Mochida, Y., Ohnishi, T., Srisawat, W. 2000. Top/root biomass ratio of a secondary mangrove (Ceriops tagal (Perr.) C.B. Rob.) Forest Ecology and Management.139: 127-134.

Ghose, M. and Joshi, H. 2003. Forest structure and species distribution along soil salinity and $\mathrm{pH}$ gradient in mangrove swamps of the Sundarbans. Tropical Ecology. 44(2): 195-204.

Ghose, M. and Joshi, H. 2003. Journal of Tropical Ecology. 44: 197-206. 
Gomes Soares, M.L. and Schaeffer-Novelli, Y. 2005. Above-Ground Biomass of Mangrove Species. I. Analysis of Models. Estuarine, Coastal and Shelf Science. 65(1-2): 1-18.

Gong, W.K. and Ong, J.E. 2013. Structure, Function and Management of Mangrove Ecosystems. ISME Mangrove Educational Book Series No. 2. International Society for Mangrove Ecosystems (ISME), Okinawa, Japan, and International Tropical Timber Organization (ITTO), Yokohama, Japan.

Heip, C. 1974. A New Index Measuring Evenness. Journal of the Marine Biological Association.54(3): 555.

Jayakody, J.M.A.l., Amarasinghe, M.D., Pahalawattaarachchi, V. And De Silva, K.A.W.L. (2008). Vegetation structure and potential gross primary productivity of mangroves in Kadolkelein Meegamuwa (Negombo) Estuary, Sri Lanka. Sri Lanka J. Aquat. Sci. 13: 95-108.

Kamaruzaman, J., Kasawani, I. and Nurun-Nadhirah, M. I. 2007. Biological Diversity Assessment of Tok Bali Mangrove Forest, Kelantan, Malaysia, wseas transactions on environment and development, 2(3).

Kato, S., Komiyama, A. and Poungparn, S. 2005. Common Allometric Equations for Estimating the Tree Weight of Mangroves. Journal of Tropical Ecology. 21(4): 471-477.

Komiyama, A., Havanond, S., Srisawatt,W.,Mochida, Y., Fujimoto, K., Ohnishi, T., Ishihara, S. and Miyagi, T. 2000. Top/root biomass ratio of a secondary mangrove (Ceriops tagal (Perr.) C. B. Rob.) forest. Forest Ecol. Manage. 139: 127-134.

Komiyama, A., Moriya, H., Ogino, K., Prawiroatmodjo, S. and Toma, T. 1988. Primary productivity of mangrove forest, in: Chihara, M. and Ogino, K. (Eds.), Biological system of mangroves. Ehime University, Matsuyama, pp. 97-117.

Miththapala, S. 2008. Mangroves. 1st ed. Colombo, Sri Lanka: Ecosystems and Livelihoods Group Asia, IUCN.

Peter J.F. and Spellerberg, I.F. 2003. A Tribute to Claude Shannon (1916-2001) and a Pleafor More Rigorous Use of Species Richness, Species Diversity and the Shannon-Wiener Index. Journal of Global Ecology and Biogeography. 12(3): 177-179.

Pinto, M.L. 1982. Distribution and zonation of mangroves in the Nothern part of theNegombo lagoon (Sri Lanka). Journal of the National Science Council of Sri Lanka. 10(2): 245-255.

Ronnback, P. 1999. The ecological basis for economic value of seafood production supported by mangrove ecosystems. Journal of International Society for Ecological Economics. 29(2): 235 252.

Saha, S. and Choudhury, 1995. Vegetation analysis of restored and natural mangrove forests in Sagar Island, Sundarabarns, east coast of India, Indian journal of Marine sciences, 24, 133-136.

Shannon, C.E. and Weaver, W. 1949. The mathematical theory of communication. The University of Illinois Press, Urbana, 117pp.

Spalding, M., F. Blasco and C. Field, 1997. World Mangrove Atlas. The International Society for Mangrove Ecosystems, Okinawa, Japan . 178 pp.

Tam, N.F.Y., Wong, S.Y., Lan, C.Y., and Chen, G.Z. 1995. Community structure and standing biomass of a mangrove forest in Futian Nature reserve, Shanzhen, China. Hydrobiologia. 295: 193-201. 